\title{
Imaginaries of nuclear energy in the Portuguese parliament: Between promise, risk, and democracy
}

Public Understanding of Science

(C) The Author(s) 2016

Reprints and permissions: sagepub.co.uk/journalsPermissions.nav

DOI: I0.II77/09636625I6662738 pus.sagepub.com

(S)SAGE

\section{Tiago Santos Pereira}

University of Coimbra, Portugal

\section{António Carvalho}

University School of Arts of Coimbra, Portugal; University of Coimbra, Portugal

\section{Paulo F.C. Fonseca}

Federal University of Santa Catarina, Brazil

\begin{abstract}
This article explores the evolution of the nuclear energy debate and its associated controversies in the Portuguese parliament. The analysis focuses on the dictatorial regime of the New State (from the beginning of the nuclear program in 195 I until the 1974 revolution) and on the democratic period (post-1974). Portugal, as an exporting country of uranium minerals, significantly invested in the development of a national capacity in nuclear research, but never developed an endogenous nuclear power infrastructure. Through the analysis of parliamentary debates, this article characterizes the dynamic evolution of the Portuguese sociotechnical imaginary on nuclear energy and technology interlinked with ambivalent representations, including the promise of nuclear energy as key for the constitution of a technological Nation or as prompting new sociotechnical risks.
\end{abstract}

\section{Keywords}

energy policy, governance of science and technology, nuclear energy, participation in science policy, representations of science

\section{Introduction}

Although not materialized in concrete and melting atoms, the Portuguese Nuclear Plant has been part of people's concerns and expectations for a long time, and this issue has influenced the Portuguese political agenda over the last half-century. While in the dictatorial period of the New

\section{Corresponding author:}

António Carvalho, Centre for Social Studies, University of Coimbra, Praça Dom Dinis, Coimbra 3000-995, Portugal. Email: antoniomanuelcarvalho@gmail.com 
State there was a homogeneous technopolitical discourse on nuclear energy as the promise of technological prowess and economic development (Hecht, 1998), the transition to a democratic society yielded the emergence of opposing voices in the debate. These dissenting voices have questioned the desirability and safety of a Portuguese power plant and contributed toward more complex forms of argumentation and justification. Nowadays, these voices celebrate the fact that there is no nuclear power plant in Portugal.

The data analyzed in this article stem from a wider project on the coproduction of society and technology (S\&T) through the development of nuclear technologies and knowledge in Portugal. Through a comprehensive analysis of the Members of Parliament's (MPs) interventions on nuclear energy, we investigated the historical evolution of Portuguese nuclearities, that is, the social, cultural, and economic entanglements that emerge alongside nuclear ontologies (Hecht, 2006), focusing on parliamentary debates.

Following a coproductionist perspective (Jasanoff, 2004), we employ the concepts of civic epistemology (Jasanoff, 2005) and sociotechnical imaginary (Jasanoff and Kim, 2009, 2013) to discuss the evolution of the debate on nuclear energy. As we have suggested elsewhere (Pereira and Fonseca, 2013), these concepts are appropriate tools to analyze nuclear controversies in Portugal. Although Jasanoff's (2004) analysis deals mostly with the executive branch, in this article we focus on parliamentary debates, recognizing that they constitute rich discursive formations which depict different ways of framing Portuguese nuclearities. Since Portugal has never built a nuclear power plant, these debates allow us to analyze the evolution of this sociotechnical controversy and its associated frames, entangled with historical, political, and social factors.

Drawing on both quantitative and qualitative methods, we identified four different periods of parliamentary debates, distinguished according to the historical context in which they have been developed. The analysis sheds light on the gradual political incorporation of a public refusal of nuclear energy and the emergence of risk and sustainability concerns in the national energy sociotechnical imaginaries.

Parliamentary debates are a relevant historical source of political argumentation. Although no deliberation on nuclear energy has occurred in the recent democratic period, the political process of non-decision-making provides significant data on the evolving nuclear sociotechnical imaginaries. While the validity of parliamentary debates to assess civic epistemologies can be questioned, the parliament is a relevant historical source, being decisively affected by changes in the Portuguese society. Since Portuguese nuclearities emerged initially as a symbol of technological development and were progressively reconfigured as potential health and environmental hazards, they are an interesting case study to investigate the dynamic construction of S\&T, as well as the relationship between politics and public perceptions of science.

\section{Brief history of the Portuguese nuclear program}

Since 1907 Portugal was aware of significant radium-uranium reserves in its territory and had consistently established mining activities, initially under the operation of a British company and later with a partial and total nationalization of the mining enterprise. By the end of World War II, Portugal was the third largest producer of uranium concentrates in the West (Oliveira, 2002). However, these uranium oxides were not used for local research activities, being instead sold to the United Kingdom and the United States (Oliveira, 2002). Following the Atoms for peace incentives of the early 1950s (Eisenhower, 1953), the dictatorial government commissioned a Nuclear Energy Board to form and gather the elite of national scientific expertise in order to develop the country's capacity to use its own uranium reserves in the near future. From then onward, the possibility of having a nuclear plant in their backyards has raised different reactions from the Portuguese population. 
The initial monolithic conception of nuclear as the best rational choice for the country's development was directly linked to the unquestionable authority of the dictator's bureaucratic expertise. The MPs, all belonging to the dominant single-party (The National Union), uncritically legitimized the authority of the government. For two decades, they confirmed and stood by every decision announced. In 1968, studies about the location of the future power plant were commissioned and the government announced that the construction should begin in the mid-1970s. In March 1974, it was announced that the plant would be located in Ferrel, a small fishing village located $100 \mathrm{~km}$ from Lisbon.

During the dictatorial period, there was a consensus that it was just a matter of developing the right conditions in order to build the first nuclear power plant, and such project was closely connected with the optimization of energy reserves, thus benefiting the national economy. However, on 25 April 1974, a coup d'état overthrew the dictatorial regime before the construction began.

After 41 years of dictatorship, the so-called Carnation Revolution completely remodeled the country's political institutions and practices. Reformist and progressive ideology was ubiquitously incorporated into all kinds of social relations (Schmitter, 1999). Particularly, the 2 years that followed 25 April 1974 were marked by turbulent political instability. Distinct modes of public reasoning concerning the meaning and outcomes of the revolution were under dispute (Santos, 1984). The parliament became a constitutional assembly, but the fractures and struggles were so severe that the country had six different governments and various attempts of new coups in only 18 months. When a new constitution was approved, on 25 April 1976, a reasonable stability was achieved and the parliament could finally begin its normal democratic function.

Nuclear energy would soon be brought up again in the political agenda. The first revolutionary governments, urging to implement the so-called three D's revolutionary slogan-Democratization, Decolonization, and Development - recognized the nuclear program as a step to accomplish the third demand. In 1975, and disregarding potential public reactions, the Minister of Energy and Industry announced some preliminary construction work to facilitate the building of Ferrel's nuclear power plant (Oliveira, 2002). Apparently, there had been a continuation of the dictatorial orientation toward the use of nuclear energy, conceiving the national uranium reserves as the justification for such an endeavor.

What the politicians did not expect was the decisive role played by the first D-Democratization. The overwhelming democratization ultimately led to the emergence of a strong civic opposition, kept invisible for years. Once organized, it would strongly interfere in many processes. Unexpected protests popped up, initially from local citizens from Ferrel in 1976, who spontaneously marched to the construction site and forced workers to abandon their posts. In the next few months, the first national environmental groups, who brought the agenda and tactics of global anti-nuclear movements into the Portuguese context, fostered a widespread public opposition. With the help of prominent scientists who contested the technical grounds supporting the nuclear option, the activists published books, pamphlets, and manifests, mobilizing artists and intellectuals (Cautela et al., 1977; Domingos, 1978; Torres, 1977).

One of the first governmental reactions was to call for a White Book on Nuclear Energy, developed by experts, in order to technically evaluate the pros and cons of the nuclear option (Sousa et al., 1978). However, the publication of the report was delayed and the decision makers could no longer ignore the increasing public rejection of the nuclear option.

The possibility of a nuclear development was again raised in 1981 with the presentation of the National Energy Plan (PEN, for its Portuguese acronym). This 1000-page document was presented as the state of the art on Portugal's energy policy. The PEN pondered the beginning of energy production in 1995 under the scenario of a small economic growth.

This document triggered more opposition from environmental groups, leading to a number of debates (Schmidt, 2003). Similar to what had happened following the White Book on Nuclear 
Energy, the voices of dissent highlighted the biased character of the available scientific studies and were particularly critical toward the executive commission (Amigos da Terra, 1987). In 1984, a reviewed version of the PEN was elaborated, this time with a less ambitious program of nuclear development, but still considering it as an option for future energy development. In that same year, the national energy company, EDP, identified two potential locations for the construction of two power plants, and the commission in charge of the renewed PEN reviewed the work according to a set of recommendations of International Atomic Energy Agency (IAEA) experts (Oliveira, 2002). However, the Parliament was never informed about the results of the study, including potential locations for the construction of the plant.

In 1986, after the overwhelming impacts of Chernobyl, nuclear energy was deliberately excluded - the emphasis was now on the use of natural gas and coal and on the diversification and rational use of energy resources. In that same year, the Secretary of State for the Environment publicly declared that Portugal had abandoned the nuclear option, a decision that would later be ratified by the Prime Minister in 1987 (Oliveira, 2002). If nuclear energy was already too expensive for Portugal and too difficult to support due to popular opposition, the implications of Chernobyl decisively undermined the Portuguese nuclear project.

This issue was kept silent until 2005, when a private investment group, led by a Portuguese entrepreneur from the energy sector, publicly announced their intentions to build a nuclear power plant. Nuclear energy was understood as a non-carbon emitting technology, therefore a sustainable option. However, the investors' ambitions never came to fruition, and the idea was abandoned, which could be partially explained by the financial crisis of 2008 and its harsh economic impacts. The Fukushima disaster in 2011 eroded any possible attempt to restore public trust (FORATOM, 2012), setting the nuclear plant development back to the canceled project shelves.

\section{The Parliament: Snapshots of sociotechnical imaginaries and civic epistemologies}

National Parliaments play a preponderant role in sociotechnical decisions. Science and Technology Studies (STS) have produced a consistent body of scholarly work that illustrates the blurred boundaries that shape and define technopolitical decisions (Guston, 1996, 1999; Jasanoff, 2011). In order to pursue society's best interest, MPs have to consider different expert-based views about the inherent risks and uncertainties of technoscientific issues. The construction of political consensus on sociotechnical controversial issues is a pivotal process that may take place in different forms or spaces, from transparent public counseling agencies to ad hoc solutions based on secret lobbying. Contrasting with other national contexts (Klüver et al., 2000; Wood, 1997), the Portuguese parliament never had its own technology assessment body; therefore, most sociotechnical controversies have led to the constitution of ad hoc commissions (Nunes and Matias, 2004b).

For the purpose of this article, we analyzed the historical evolution of MPs' claims as reflecting a wider framework of political reasoning on nuclear energy. Although the efficiency and legitimacy of representative democracies have been highly criticized in recent decades, in particular regarding their ability to tackle technoscientific controversies (Callon et al., 2001), national parliaments are still central institutions regarding the sanctioning of legislation, making available official arguments and policies. Thus, the parliament is a primary source for inquiring about the Portuguese political positioning on nuclear energy. The historical evolution of political attitudes and discourses on nuclear energy reflects the dynamic processes that helped to shape the current public reasoning on this issue and also wider changes regarding civic epistemologies, "culturally specific, historically and politically grounded, public knowledge ways" (Jasanoff, 2005: 249). By analyzing parliamentary debates, while grounding them in wider historical frameworks, we will be able to see 
how political discourse progressively incorporates public concerns on nuclear energy, especially after 1974, when a new political landscape paved the ground for massive demonstrations against the nuclear option.

Parliamentary debates are highly useful in order to characterize sociotechnical imaginaries, that is, "collectively imagined forms of social life and social order reflected in the design and fulfillment of nation-specific scientific and/or technological projects" (Jasanoff and Kim, 2009: 120). Through the characterization of the historical evolution of parliamentary representations, concerns, and aspirations, we explore the various facets of the Portuguese sociotechnical imaginary on nuclear energy.

In the case of dictatorships, such as the Portuguese New State, the parliament legitimizes centralized decisions of the executive and, when necessary, provides counseling to the executive government (Rosas, 2003). Therefore, the analysis of the parliamentary sessions in this period allows us to explore the reasoning and imaginary of the authoritarian regime.

\section{Methodology}

The Portuguese parliament website provides an online database with the integral transcription of all plenary interventions since $1821 .^{1}$ For the period of the New State, it offers the complete texts of the journals and sessions of the National Assembly and Corporative Chamber. Although the dictatorial government controlled both houses, there were normal deliberative sessions that can be scrutinized through the search engine on the parliamentary website. The transcripts of all the sessions of the Constitutional Assembly - comprising the plenary sessions that took place in 19751976 and that eventually formulated the present constitution-are also available. From 1976 onward, the catalogue offers the full transcription of all plenary sessions in the Assembly of the Republic, the single national parliamentary house in operation.

Initially, we identified all the sessions where the expression nuclear energy was mentioned, from the end of the World War II until 2013. This search resulted in 96 diaries for the New State period, 6 diaries for the Constitutional Assembly and 112 diaries for the Third Republic period, that is, from 1976 to the present. We have analyzed each one of these diaries, filtering off the bureaucratic dispatches and considering only the occasions when an MP was discussing the issue of nuclear power, reaching 226 entries. We then proceeded with an exhaustive categorization of each parliamentary statement. When the issue was debated in plenary, we considered each MP's intervention separately. The extension and scope of the interventions in the diaries are heterogeneously distributed, oscillating between brief bureaucratic statements of one single MP to a wide engagement of different MPs in the parliament.

After collecting this data, we coded the material according to four dimensions. The first two are essentially descriptive and the last two are more analytical. The first set is formed by the party affiliation (only for the democratic period) and the context or topic of the intervention (construction of a power plant, request for studies, concerns with foreign accidents, and so on). The second set of information has been constructed following the individual analysis of each statement - we identified the MP's stance on nuclear energy in Portugal (pro, against, or neutral/undefined) and the framing that was used to justify his or her stance (economic, political, social, environmental, risk, and scientific).

Frames are devices that organize a selective representation of a specific issue (Conrad, 1997), conditioning the formation of public opinion (Gamson and Modigliani, 1989) and social movements (Benford and Snow, 2000). To frame something is to emphasize certain aspects and to overlook others. STS scholarly work has highlighted the performative dimensions of ontologies (Mol, 1999); similarly, the politics of truth of a given object (such as Portuguese nuclearities) is enmeshed 
with practices, histories, discourses, and forms of power (Foucault, 1980). Parliamentary debates display different ways of framing nuclearities in order to achieve specific political outcomes. For instance, the topic of the construction of a nuclear power plant, when framed according to an economic perspective, may justify the high cost of the endeavor with the future independence on foreign oil, disregarding potential safety concerns. The knowledge resources deployed by political discourse reshape the nuclear object, illustrating the complexities of nuclear ontologies.

Meanwhile, based on their political relevance - understood here as their connection with historical events or decisions (such as the Carnation Revolution or Chernobyl) — we have selected specific debates from each significant period. In this sense, whereas most of the interventions do not present the same "ethnographic density," it was possible to identify and qualitatively analyze discourses that provide some nuances of the deployed sociotechnical imaginaries and that helped us infer about the impacts of emerging civic epistemologies. Therefore, we have developed a macroanalysis of the complete set of parliamentary interventions while also undertaking a microanalysis of specific discourses, capturing some of the historical dynamics of the political and public reasoning on nuclear energy in Portugal.

\section{Results}

While looking at the chronology of interventions, one may not find a pattern or a direct correlation with the major political changes that took place in Portugal. Nevertheless, the peaks correspond to specific historical moments of decision-making. For instance, during the New State, MPs deployed policies for the immediate construction of a national uranium producer, in 1958, and for the future construction of the power plant that would later have its location in Ferrel, in 1967. During the democratic period, we can identify two peaks taking place in 1981 and 1984 . These correspond to debates about two national energy plans, although these were never submitted to the parliament and the MPs didn't explicitly deliberate on the issue.

Indeed, this aspect demands another clarification about the particularity of the data set: the contrasting nature of the interventions in the two periods, before and after the Carnation Revolution. It is fair to describe them as opposite: while in the first part there is no discussion and much deliberation, in the second period there is no decision-making and much discussion. Interestingly, the national parliament has not deliberated on the development of local nuclear energy plants. The issue was significantly debated, but relevant projects-including the aforementioned national plans - were never voted.

It is also particularly interesting to note that, despite our initial expectations, there were no major occurrences/peaks at the time of the broader public debate triggered by Ferrel's protests, including the request of a White Book to be submitted to the Parliament, in the late 1970s, nor any repercussion following the accident at Three Mile Island.

\section{Four periods}

There are four distinguishable periods regarding Portuguese nuclearities. The first one concerns the period dealing with the authoritarian regime, which lasted until 1974. The second period is what we call the post-revolutionary period, from the Carnation Revolution until the Chernobyl disaster in 1986, when the democratic institutions were already established and crucial decisions on the nuclear subject had already been made. During the third period, following the Chernobyl disaster, most debates draw on the international dimension of nuclear energy (including an emphasis on Spanish power plants close to the Portuguese border), since there were no more official plans to build a national nuclear power plant. The fourth period starts in the beginning of the 2000 s, when 


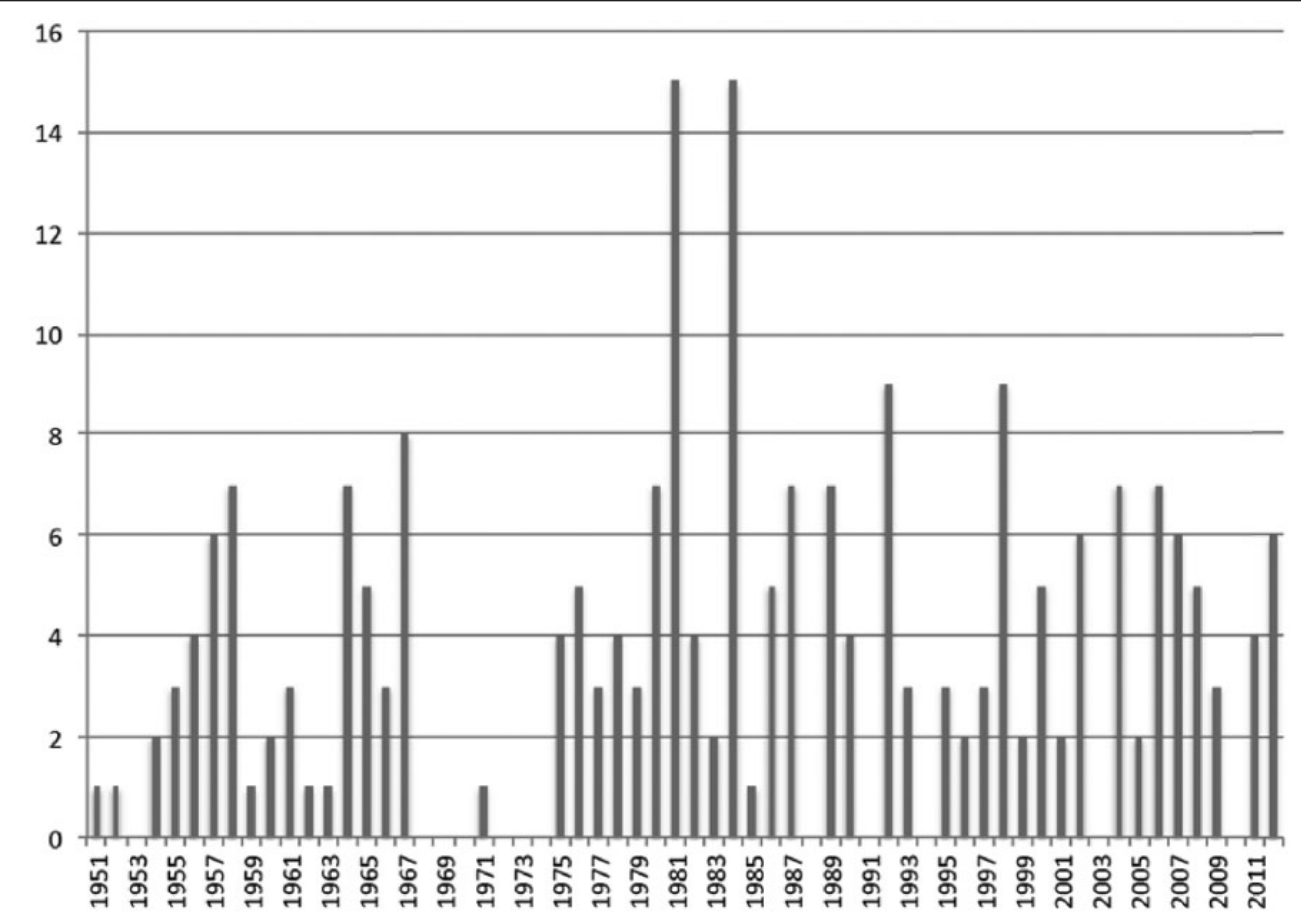

Figure I. Number of interventions per year.

the nuclear option reemerges in the international political discourse as a type of green energy. During this period, a private investment group was willing to build a local nuclear power plant and benefited from extensive media coverage - this generated heated discussions. Figure 1 shows that although nuclear energy was subsequently disregarded as a viable option for the national energy strategy, the issue was reasonably present in all four periods analyzed. There were 56 entries for the first period, 68 for the second period, 54 for the third, and 48 for the last one.

First period:The New State (1945-1974). As previously discussed, during the authoritarian regime, the development of national infrastructure and scientific expertise was an explicit government strategy. Since in the parliament there was no room for formal political dissension, this period is characterized by a homogeneous stance on the issue. As shown in Figure 2, the occurrences emerge within debates on the general energy strategy, with a clear connection with the need to take advantage of Portugal's uranium reserves. MPs deliberate about the institutional responsibilities of national agencies, including the Nuclear Energy Board, and economic aspects of the energy reserve.

According to Figure 3, it is not surprising to note that, in the first period, economic aspects have mostly framed the issue since it emerges hand in hand with the national energy strategy. Meanwhile, MPs were also keen on providing scientific explanations about the potential of this energy source of the future. As nuclear energy was still an emerging technology for peaceful purposes, it was also expected that the parliament, confirming the authority of the government, was devoted to educating the population about the promises of this energy source.

The following statement is a good illustration of the MPs' interventions during the New State: 


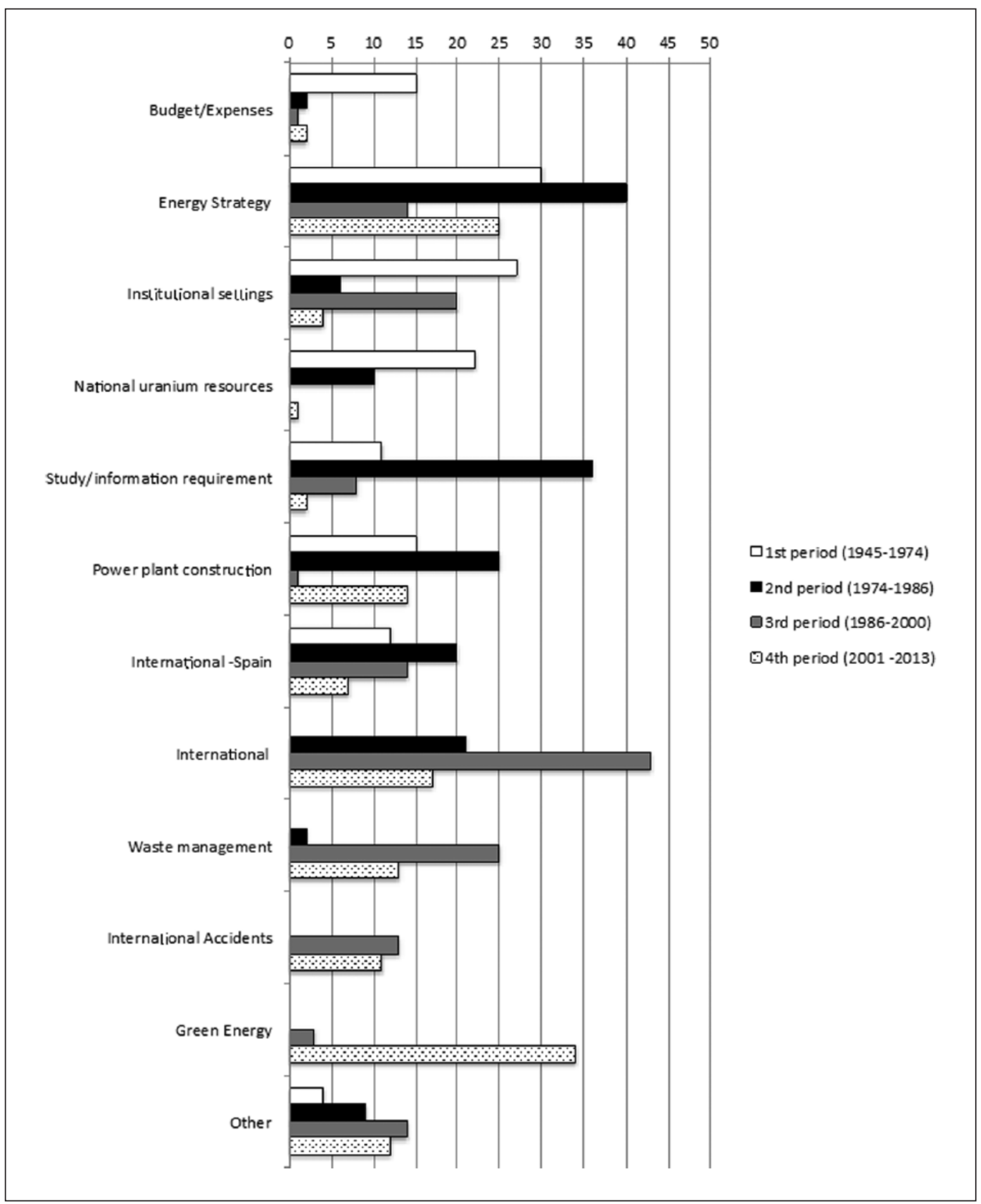

Figure 2. Topics discussed in each period, by number of occurrences.

The Speaker: It is imperative that, in the dawn of the nuclear age, we do not set ourselves apart from those countries that, due to their economic wealth and their advances in Physics, began this new era.

Plenary: $\quad$ Very well! 


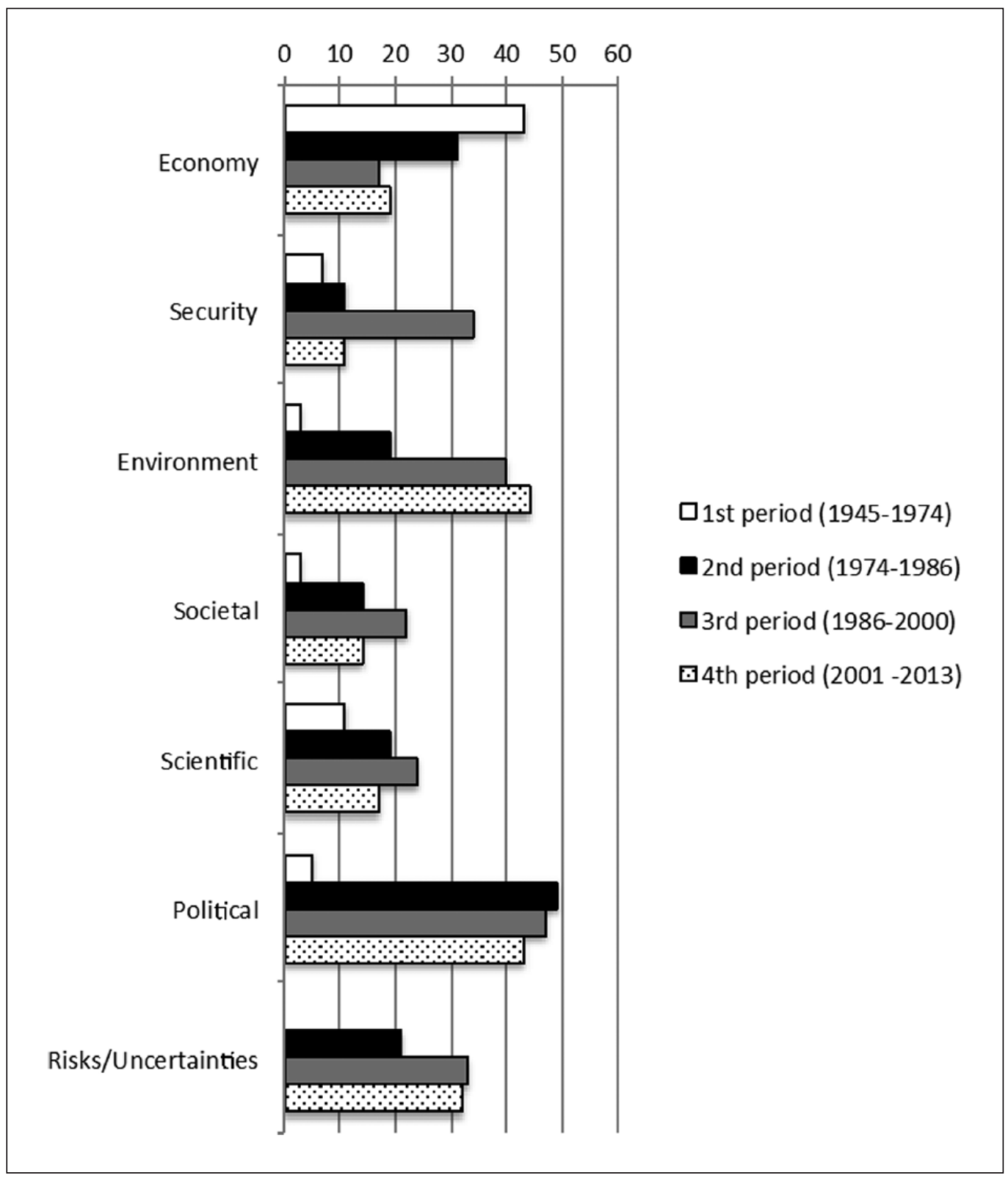

Figure 3. Frames deployed in each period, by number of occurrences.

The Speaker: To postpone the publication of the current diploma, which will create the first group of nuclear scientists, would be a tremendous mistake; since science does not stop, to recover our scientific underdevelopment in the future would require serious effort. Perhaps we would put ourselves in a similar situation to Japan after its first industrialization attempt. (José Sarmento, 17 February 1954, p. 482) 
It is also interesting to note that although the military purposes were never explicitly mentioned, they are evidently also present as a concern that justifies the development of nuclear capability. The military applications of this type of energy were already part of early Portuguese nuclearities, at least as part of the dictatorial unconscious, mirroring the national attempt for self-determination. For instance, in that same speech, José Sarmento, MP, states that

We hope (and may God help us) that the dawn of the nuclear age is not darkened by the military applications of atomic energy. However, and if that happens, the knowledge we will acquire on that energy resource will more easily allow us to protect ourselves from its destructive effects! (José Sarmento, 17 February 1954, p. 483; authors' emphasis)

The positive attitude toward the issue is a reflection of the post-war Atoms for Peace mentality, when nuclear energy was globally seen as the propeller of economic development, leading to the dawn of a nuclear age. Meanwhile, science is pictured in its classical form, an endless frontier (Bush, 1945) that must be constantly supported in order to generate beneficial technological applications. A decade later, a reference to the local power plant would already appear in the National Plan for economic development:

The two major guidelines for the conduction of this research are the exploration of national nuclear fuels and the development of techniques to build nuclear power plants. [...] Regarding the second aspect, it was determined, in the chapter entitled Energy of the current Plan, that a nuclear power plant would be built in Portugal around 1975, therefore it is necessary to intensify the research that will allow us to develop these techniques. (III National Plan, 1968-1973, 7 November 1967, p. 153)

Thus, if during the 1950s the speeches highlighted the need to develop nuclear science expertise, in the late 1960 s it was a given as a premise to accomplish what had already been determined: the construction of a Portuguese nuclear power plant.

Second period:The aftermath of the democratic revolution (1974-1986). Although the revolution led to profound social and political changes, the nuclear option was not immediately abandoned. However, the birth of democracy resulted in an increasing demand for accountability regarding the nuclear option, as elicited by the sheer number of debates on this matter (Figure 1), including various requests for new studies, resulting in the multiplication of frames (Figures 2 and 3). For instance, in the following quotation, an MP mentions a nation-wide public debate on the nuclear option, recognizing the need to democratize decision-making processes, including those involving sociotechnical controversies:

One of the initiatives that should be highlighted, and that took over a year and a half to prepare, is the Second National Encounter of Energy Policy, taking place on the $25^{\text {th }}$ and $26^{\text {th }}$ of March at the National Laboratory of Civil Engineering. There were numerous interventions on specific themes, and the discussion and analysis of the issues at stake benefited from the participation of members of workers' commissions as well as scientists, engineers, economists, other technicians and workers, citizens that live in PenicheFerrel, ecologists and University students. We should also mention the informal participation of technicians and other workers of EDP; we hope that they won't suffer any retaliation due to their courage and willingness to publicly express their opinions on a topic that clearly transcends the internal affairs of their corporation. (Sousa Marques (Communist Party), 26 May 1977, p. 3824; authors' emphasis)

The emergence of social and environmental movements is mentioned in the parliament; this not only indicates an increasing trend to include the public in processes of parliamentary discussion 
but also highlights the recognition of new risks and uncertainties, constituting a new way of framing Portuguese nuclearities. If, initially, Portuguese nuclearities were understood as a sort of black box (Latour, 1987), linked to an attempt to optimize energy production, after 1974 the discourse is permeated by a multiplicity of factors, including the environment:

On the 21st and 22nd it took place, in Caldas da Rainha, the first Festival for Life, against Nuclear Energy, promoted by a number of ecologists from Lagos, Lisbon, Coimbra and Porto. Many youngsters from all over the country, and without any financial support, have joined the Festival.

The Festival consisted of exhibitions, movies, debates, colloquia and the informal sharing of ideas between participants. Afonso Cautela, António Saraiva, Delgado Domingos, Jacinto Rodrigues and José Marques, as well as members of the Commission against Pollution of Alviela and the Inhabitants' Committee of Ferrel also participated. Most of the participants believed that it's better to be active today than radioactive tomorrow. (Alberto Andrade (Socialist Party), 24 January 1978, p. 1112; authors' emphasis)

The progressive permeability of Portuguese nuclearities to democratic, environmental, and participatory forces is also accompanied by the politicization of the nuclear option. Although the main concerns were still related to economic aspects, there was room for political debate over the liability and neutrality of the technical statements, which dominated the discussions about the White Book and the following PENs. Meanwhile, the role of international dimensions became salient, highlighting the impact of external influences on national decisions - the following statement is particularly illustrative:

Following the intervention of the MPs, one could suppose that the entire opposition is against the nuclear option. According to my knowledge, only the ASDI, ${ }^{2} \mathrm{UEDS}^{3}$ and $\mathrm{UDP}^{4}$ were against the development of a nuclear power plant. It's quite odd, indeed, that all the questions, some of them reasonable, were posed by those who have frequently stated that, if the nuclear reactors are Soviet and serve the working class are good, whereas if they serve the bourgeoisie, and are American, are bad. Some of the questions, however, are quite striking, and they remind us of the silence of the Socialist Party, since all the supposedly leftist press announced, some days before the visit of President Miterrand to Portugal, that the selling of French nuclear stations was on the negotiation agenda. No one from the Socialist party has provided any clarifications, and we don't know if the Socialist Party is in favor of the US made Westinghouse nuclear stations or prefers the Westinghouse stations built in France, under American license, by FRAIMATOM. (Luís Coimbra (Popular Monarchist Party), 18 March 1982, p. 2810)

The MP also alludes to the main parties' dread of assuming any favorable or opposing stance on nuclear energy, recognizing that a controversy had been set up, and it was not politically desirable to stand by one of the two sides. Consequently, in this period, the predominant standpoint was that of neutrality.

Third period: International follow-up (1986-200I). Although international aspects started emerging as salient in the previous period, after the Chernobyl disaster and Portugal's official abandonment of the nuclear program, they are the predominant focus of parliamentary debates during the third period of analysis. The nuclear threat is no longer coming from the inside - it is reasonably present in the European neighborhood. The severity of Chernobyl's impact has undoubtedly shaped MPs' attitudes, and Portuguese nuclearities are no longer exclusively connected with the national energy strategy - their focus shifts to issues such as waste management and the governance of foreign accidents. As put by an MP, 
The incidents of Three Mile Island, in the US, in 1979, and, more recently in Chernobyl, Soviet Union, have demonstrated that the danger is identical, regardless of its ends. (Raul de Brito (Socialist Party), 13 May 1986, p. 2519)

The framing is still political; however, it is strongly directed toward international relations. In particular, Spanish power plants occupy a significant share of Portuguese MPs' anxieties, as exemplified by the following statement:

Issues of responsibility, ethics and transparency oblige us to question the legitimacy of the Spanish State to impose upon Portugal (that has rejected nuclear energy) this option; these values also demand us to be vigilant regarding what is going on in the Iberian Peninsula; they require us to overcome the status of mere observers of what is going on in Spain, unable to defend our interests and ignoring their programs, including nuclear energy. The news coming from Spain oblige us to be mindful and responsible in accompanying these dossiers, fostering a cautious attitude towards the location of Spanish nuclear power plants, whether near international rivers, such as Tejo, or in Almaraz, close to our borders. (Isabel Castro (Green Party), 29 April 1998, p. 2136)

The proximity of Spanish power plants fueled the Portuguese imaginaries of the nuclear threat, compromising the relationship between the two Iberian countries. Nuclearities, in this case, are interlinked with issues of national security, due to the possibility of disasters taking place in Spain. Moreover, the concerns moved from the power plants themselves to the risks related to the management of international nuclear waste. Issues concerning the disposal of radioactive waste at sea, in the Azores, have been recurrently brought up.

Fourth period: Nuclear as green energy (200I-20I3). With the ratification of the Kyoto Protocol in 1999, climate change concerns have pervaded parliamentary debates on nuclear energy. From that moment on, it was argued that the nuclear option is a clean energy since it does not contribute toward global warming through the emission of $\mathrm{CO}_{2}$, contrasting with fossil fuels. However, Portuguese MPs have not endorsed this view, as suggested by the following quotation:

The [European] Commissioner [Loyola de Palacios] argues that nuclear energy is synonymous with clean energy. In fact, there is no emission of carbon dioxide or of other gases that contribute towards the greenhouse effect- that is true! However, we cannot consider nuclear energy as clean. Nuclear power stations have been riddled with accidents, radioactive leaks and even explosions. (Salvador Messano Cardoso (Social Democrats), 8 May 2002, p. 249)

During this period, the possibility of building a nuclear power plant reentered the political debate, due to the initiative of a group of private investors who were willing to revolutionize Portuguese nuclearities in 2005. However, and contrasting with previous debates, instead of stressing the economic desirability of the nuclear option, MPs were concerned with environmental impacts and risks, discrediting the supposedly green nature of nuclear energy, as promoted by the pro-nuclear lobby:

Regarding the [intervention of] MP Francisco Madeira Lopes, I would like to state that one of the lies that has been often propagated concerns the cleanliness of the production of energy. In fact, this is one of the recently used arguments, ignoring, or attempting to conceal from the public, the fact that nuclear energy is far from being a clean energy. Not only does it contribute to the emission of $\mathrm{CO} 2$ during the extraction of uranium but also produces residues that stay radioactive for tens of thousands of years. Therefore, this argument is actually flawed and deceives the public. (Alda Macedo (Left Block), 26 April 2006, p. 5376) 


\begin{tabular}{|l|l|l|l|}
\hline Period & Pro-nuclear (\%) & Neutral/Indefinite (\%) & Against (\%) \\
\hline 1st period (1945-1974) & 77 & 23 & 0 \\
\hline 2nd period (1974-1986) & 16 & 52 & 32 \\
\hline 3rd period (1986-2000) & 2 & 40 & 58 \\
\hline 4th period (2001 -2013) & 0 & 9 & 91 \\
\hline
\end{tabular}

Table I. Analysis of MPs' stances toward nuclear energy in the four periods.

Although the possibility of building a nuclear power plant has been brought back to the political agenda, the MPs have taken a quite distinct approach from the first two periods. At this time, there was not even one single intervention to support the entrepreneurship. As we will suggest, this corroborates the fact that there was a shift in the national sociotechnical imaginary. In its final shape, nuclear energy is significantly absent from the official governmental and main parties' agendas, although there has been an international and local movement toward its reintroduction into the energy strategies.

\section{Discussion-The evolution of stances throughout the four periods}

The analysis of the evolution of MPs' stances indicates that, if during the New State there was a consensus toward the construction of a power plant, in the last period most representatives are against the nuclear option (Table 1). Simultaneously, if during the post-revolutionary period there is some division, with the majority of MPs being neutral, progressively there is a transition toward the rejection of nuclear energy.

While the authoritarian government stood in favor of the nuclear option, after the democratic coup d'état there is a progressive transition from relatively neutral and pro stances toward a generalized opposition to the construction of a nuclear power plant in Portugal.

In other words, there has been a shift from a sociotechnical imaginary that could be depicted as "Portugal as moved by nuclear power" to "Portugal as threatened by nuclear power." However, this shift has not been synchronized with the major political ruptures experienced after 1974. It appears that visions grounded on the acceptance of nuclear energy as a resource and not as a menace were only gradually swept away. It is fair to say that democratic aperture has given voice to pre-existing dissent, which gradually, through a decade or so, reached public debates and forced the political class at least to hide their favorable judgments about a nuclear power plant in Portugal.

\section{Overwhelming layers of complexity}

One could argue that Portuguese nuclearities became increasingly complex throughout time. As Figure 4 indicates, if initially nuclearities are embedded in economic issues and the topic is mostly focused on the optimal use of national uranium resources, directly linked to the national energy strategy, the tendency is toward the introduction of new sets of arguments, eliciting an overwhelming complexity that suspends the initial picture of a black box. If, initially, Portuguese nuclearities are entangled with the sociotechnical imaginary of a nation that wants to extend its energetic and scientific capability - as hubris - Portuguese nuclearities tend to be increasingly enacted as a 


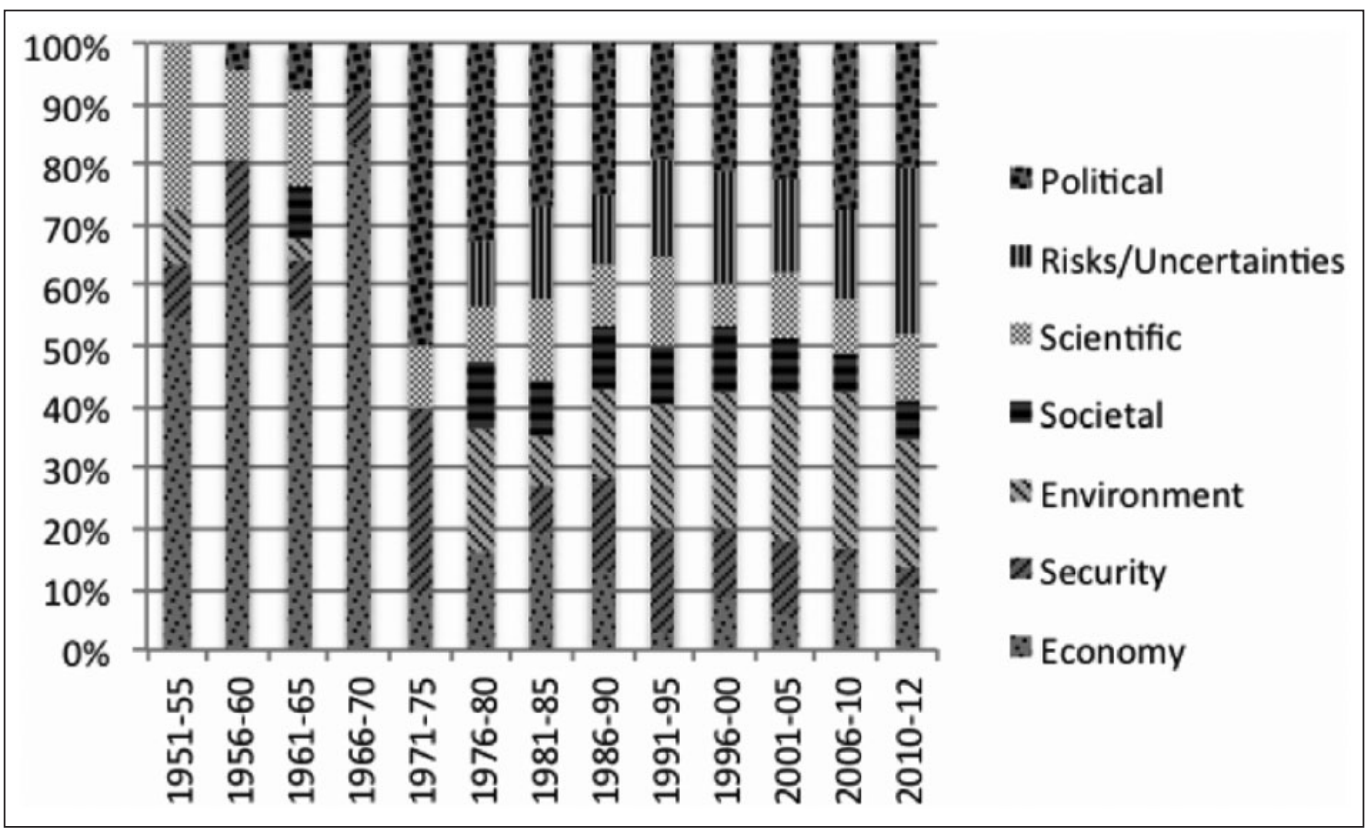

Figure 4. Timeline of the framings used by MPs.

problem child, as its representation becomes affected by aspects such as risks, the environment, international relations, and the public. Portuguese nuclearities progressively become a sociotechnical controversy, contrasting with its initial representation of a promise, reflecting a utopian and optimistic vision of S\&T as fostering progress, power, and wealth. The birth of democracy has darkened nuclear ontologies, compromising their modern, early enactment.

The above picture, dealing with the evolution of framings, is self-explanatory-Portuguese nuclearities emerge initially as a black box, determined by economic aspects, and the tendency is toward complexity. Portuguese nuclearities become increasingly affected by the winds of democracy, the voices of the public, international incidents, external relations, and the environment. Portuguese MPs progressively represent nuclear ontologies as reflecting this growing complexity, mirroring the heterogeneous dimension historically attained by nuclear energy. There is a transition from power and hope toward complexity and uncertainty. In this regard, it is quite interesting to note, in the last period, the dissemination of the topic of green energy, as well as the extensive use of the notions of risks and uncertainties, clearly outweighing the economic dimension. The increasing importance of the environmental dimension illustrates broader trends in political styles of reasoning, recognizing the need to develop efficient mechanisms to tackle the environmental aspects of risks (Beck, 1992; Callon et al., 2001; Latour, 2004). These illustrate the progressive environmentalization of Portuguese and international nuclearities (Bickerstaff et al., 2008; Rothman and Lichter, 1987).

\section{Sociotechnical imaginaries and Portuguese nuclearities- Thematizing a transient civic epistemology}

Although in the 2000s there was a nuclear power resurgence in a number of European countries (Teravainen et al., 2011), that was not the case in Portugal. One could argue that environmental and 
risk aspects overpowered these more recent attempts to revitalize the nuclear option. This also mirrors broader international trends toward the growing complexity and plurality of nuclear ontologies. Why have Portuguese politicians overlooked the revival of the nuclear option, as opposed to other European countries? We have previously suggested that the emergence of a pluralist civic epistemology in the post-revolutionary period affected the public reasoning on nuclear energy, bringing forth a whole new set of arguments that inflected the public discourse, exposing the previously hidden contradictions of the nuclear project (Pereira and Fonseca, 2013).

Environmental groups managed to raise public awareness on the inherent risks of the nuclear endeavor, and politicians became aware of the public rejection and the unaffordable economic costs of such an option. A nuclear-free sociotechnical imaginary became so deeply imprinted in the collective consciousness that, when the issue was pushed back into the political agenda, in the early 2000s, it resulted in a blatant rejection. Instead of following the nuclear path, Portugal has invested in renewable sources of energy (Krajacic, Duic and Carvalho, 2011; Reiche and Bechberger, 2004) — wind turbines and solar panels were slowly introduced into the Portuguese landscape, while nuclear reactors belong to a future that never came to be, a failed technoscientific utopia of the dictatorial era.

After the birth of democracy, the debate on nuclear energy was decisively marked by the clear public rejection of this technology and by a growing concern with risks and the environment. This clearly contrasts with other sociotechnical controversies that emerged in the 1990s and 2000s in Portugal, where the general public and lay knowledge were utterly disregarded (Nunes and Matias 2004a; Nunes et al., 2004; Pereira et al., 2008). This suggests that the case of nuclear energy in Portugal, unlike other technologies and sociotechnical controversies (including Genetically Modified Organisms (GMOs) and Bovine spongiform encephalopathy (BSE)), was particularly permeable to public dissent, which also highlights the limitations of this case study to establish generalizations about more general perceptions of S\&T in Portugal. Moreover, the fact that Nuclear Energy was initially associated with Fascism and Nationalism and the visibility of international accidents progressively jeopardized the project of a Nuclear Portugal.

\section{Conclusion}

The chronology of parliamentary interventions suggests that Portuguese nuclearities were initially framed in economic terms, linked to the optimal exploration of national uranium resources. Progressively, Portuguese nuclearities moved from the status of a black box toward more complex ontologies involving risks, the public, international relations, and the environment. Initially, there was a tendency to support the construction of the nuclear power plant, but progressively stances tended to be neutral and then against the nuclear option.

Our article traced the evolution of nuclearities in the Portuguese parliament. Initially, we witnessed the genesis of a hypothetical Nuclear Portugal as a product of technoscientific hubrisnuclear ontologies would be mobilized to strengthen the national economy and to foster scientific progress. After the revolution, there was a surge in social movements and participation-this has decisively shaped Portuguese nuclearities since there was a nation-wide response to the hypothetical construction of the nuclear power plant in Ferrel, including demonstrations and debates bringing together a number of actors. Political parties and their MPs did not ignore this massive opposition, and progressively they tended to reject the nuclear option.

Nuclear disasters - Three Mile Island, Chernobyl, Fukushima - also contested the initial enactment of nuclear energy as a black box. Instead of being a technoscientific promise, Portuguese nuclearities became increasingly affected by their potential impacts on the environment and on the health of individuals, particularly during the second period of analysis. MPs became aware of these 
massive demonstrations, and their discourse actively incorporated the potential negative effects of a nuclear power plant on humans and nonhumans, with risky atoms mirroring a turn to reflexivity in post-modern societies (Beck, 1992).

Risks, democracy, the public, Spanish Nuclear Plants, interventions by European Commissioners, international incidents, the environment, global warming, and political aspects decentered the nuclear debate from its early focus on the economy and national interests. Democracy, joining the European Union (EU) in 1986 (coincidently in the same year that Chernobyl took place) and the impermanence of nuclear ontologies (both nationally and internationally) turned Portuguese nuclearities into a complex entity.

Our analysis shows that the frames of nuclear energy evolved throughout time, illustrated by the transformation of the discursive strategies of MPs. As a deliberative organ, the parliament, especially after 1974, becomes a reflection of a broader civic epistemology and contributes to unfold the nuclear controversy. In that sense, the relationship between parliament and civic epistemologies can only be taken seriously after the democratic revolution, when it actually became a forum for discussion and deliberation. However, and as we have argued, the visibility of the nuclear controversy and the massive public participation contrast with other technologies, which means that, at least in the Portuguese case, civic epistemologies are technology-specific, highlighting the particularity of this case study. In fact, the debates were no longer conditioned by a rational assessment of national uranium reserves (this expression practically vanished after 1978), but by the recognition that the public would not accept lightly the construction of a Power Plant, suggesting that the socio in sociotechnical imaginaries became the most relevant aspect framing the debate.

\section{Funding}

This paper was funded by the Portuguese Science and Technology Foundation (FCT; Ref. HC/0063/2009).

\section{Notes}

1. All transcriptions are available at $<$ www.parlamento.pt $>$

2. Democratic and Independent Social Action.

3. Leftwing Union for the Socialist Democracy.

4. People's Democratic Union.

\section{References}

Amigos da Terra (1987) Antes, Durante e Depois de Chernobyl: O Nuclear no Mundo e em Portugal [Before, During and After Chernobyl: Nuclear Energy in the World and in Portugal]. Lisboa: Associação Portuguesa de Ecologistas.

Beck U (1992) Risk Society: Towards a New Modernity. London: SAGE.

Benford RD and Snow DA (2000) Framing processes and social movements: An overview and assessment. Annual Review of Sociology 26: 611-639.

Bickerstaff K, Lorenzoni I, Pidgeon NF, Poortinga W and Simmons P (2008) Reframing nuclear power in the UK energy debate: Nuclear power, climate change mitigation and radioactive waste. Public Understanding of Science 17(2): 145-169.

Bush V (1945) Science: The Endless Frontier. Washington, DC: United States Government Printing Office.

Callon M, Lascoumes P and Barthe Y (2001) Agir dans un monde incertain: Essai sur la démocratie technique [Acting in an Uncertain World: An Essay on Technical Democracy]. Paris: Le Seuil.

Cautela A, Cousteau JY, Hawkes N, Bousquet M, Clermont P and Martin CN (1977) O suicídio nuclear Português [The Portuguese Nuclear Suicide]. Lisboa: Socicultur.

Conrad P (1997) Public eyes and private genes: Historical frames, news constructions, and social problems. Social Problems 44(2): 139-154. 
Domingos JJD (1978) O Absurdo duma opção Nuclear [The Absurdity of the Nuclear Option]. Porto: Edicoes Afrontamento.

Eisenhower D (1953) Atoms for peace speech. Available at: https://www.iaea.org/about/history/atoms-forpeace-speech

FORATOM (2012) What People Really Think about Nuclear Energy. Brussels: European Atomic Forum.

Foucault M (1980) Truth and power. In: Gordon C (ed.) Power/Knowledge: Selected Interviews \& Other Writings 1972-1977. Brighton: The Harvester Press, Ltd, pp. 109-133.

Gamson WA and Modigliani A (1989) Media discourse and public opinion on nuclear power: A constructionist approach. American Journal of Sociology 95(1): 1-37.

Guston D (1999) Stabilizing the boundary between US politics and science: The role of the office of technology transfer as a boundary organization. Social Studies of Science 29(1): 87-111.

Guston DH (1996) Principal-agent theory and the structure of science policy. Science and Public Policy 23(4): 229-240.

Hecht G (1998) The Radiance of France: Nuclear Power and National Identity after World War II. Cambridge, MA and London: The MIT Press.

Hecht G (2006) Nuclear ontologies. Constellations 13(3): 320-331.

Jasanoff S (2004) The idiom of co-production. In: Jasanoff S (ed.) States of Knowledge: The Co-Production of Science and Social Order. London and New York: Routledge, pp. 109-133.

Jasanoff S (2005) Designs on Nature: Science and Democracy in Europe and The United States. Princeton, NJ: Princeton Universtiy Press.

Jasanoff S (2011) Constitutional moments in governing science and technology. Science and Engineering Ethics 17(4): 621-638.

Jasanoff S and Kim S-H (2009) Containing the atom: Sociotechnical imaginaries and nuclear power in the United States and South Korea. Minerva 47: 119-146.

Jasanoff S and Kim S-H (2013) Sociotechnical imaginaries and national energy policies. Science as Culture 22(2): 189-196.

Klüver L, Nentwich M, Peissl W, Torgersen H, Gloede F, Hennen L, et al. (2000) EUROPTA European Participatory Technology Assessment: Participatory Methods in Technology Assessment and Technology Decision-Making. Final Report. Available at: http://cordis.europa.eu/docs/publications/ 7078/70781441-6_en.pdf (accessed 10 March 2015).

Krajacic G, Duic N and Carvalho MG (2011) How to achieve a 100\% RES electricity supply for Portugal? Applied Energy 88(2): 508-517.

Latour B (1987) Science in Action. Cambridge, MA: Harvard University Press.

Mol A (1999) Ontological politics: A word and some questions. In: Law J and Hassard J (eds) Actor Network Theory and after. Oxford: Blackwell, pp. 74-90.

Nunes JA and Matias M (2004a) Agonistic spaces, contentious politics and the trials of governance: Environmental policies and conflict in Portugal. STAGE (Science, Technology and Governance in Europe) Discussion Paper 21. Coimbra: Centre for Social Studies.

Nunes JA and Matias M (2004b) Science, Technology and Governance in Portugal. Coimbra: Center for Social Studies.

Nunes JA, Pereira TS and Matias M (2004) The BSE crisis in Portugal or how to "domesticate" European regulatory policies. STAGE (Science, Technology and Governance in Europe) Discussion Paper 23. Coimbra: Centre for Social Studies.

Oliveira JDC (2002) A Energia Nuclear em Portugal: Uma Esquina da História [Nuclear Energy in Portugal: A Corner of History]. Santarém: O Mirante.

Pereira TS and Fonseca PFC (2013) Carnation atoms: Revolution, democracy and the nuclear option in Portugal. In: Science and democracy network annual meeting, Cambridge, MA, 30 June-2 July.

Pereira TS, Rodrigues AF, Carvalho AM and Nunes JA (2008) Parlamento, Conhecimento Científico e Deliberação: Dois estudos de caso no Parlamento Português [Parliament, Scientific Knowledge and Deliberation: Two Case Studies in the Portuguese Parliament]. In: Proceedings of VII ESOCITE, Rio de Janeiro, Brasil, 28-30 May.

Reiche D and Bechberger M (2004) Policy differences in the promotion of renewable energies in the EU member states. Energy Policy 32(7): 843-849. 
Rosas F (2003) Pensamento e Acção Politica: Portugal Século XX (1890-1976) [Political Thought and Action: Portugal and the 20th Century (1890-1976)]. Lisboa: Editorial Notícias.

Rothman S and Lichter SR (1987) Elite ideology and risk perception in nuclear energy policy. The American Political Science Review 81(2): 383-404.

Santos BS (1984) A crise e a reconstituição do Estado em Portugal (1974-1984) [Crisis and Reconstitution of the Portuguese State (1974-1984)]. Revista Crítica de Ciências Sociais 14: 7-29.

Schmidt L (2003) Ambiente no Ecrã: emissões e demissões no serviço público televisivo [The Environment on TV: Broadcasts and dismissals in the public service television]. Lisboa: Imprensa de Ciências Sociais.

Schmitter P (1999) Portugal: Do autoritarismo à democracia [Portugal: From Authoritarianism to Democracy]. Lisboa: Imprensa de Ciências Sociais.

Sousa A, Bettencourt AO, Oliveira JC and Sérgio R (1978) Centrais Nucleares Em Portugal: Projecto de Livro Branco [Nuclear Plants in Portugal - The White Book Project]. Lisboa: Ministério da Indústria e Tecnologia.

Teräväinen T, Lehtonen M and Martiskainen M (2011) Climate change, energy security, and risk-debating nuclear new build in Finland, France and the UK. Energy Policy 39(6): 3434-3442.

Torres I (1977) Centrais Nucleares e Meio Ambiente [Nuclear Plants and the Environment]. Lisboa: Arcádia. Wood FB (1997) Lessons in technology assessment: Methodology and management at OTA. Technological Forecasting and Social Change 54(2-3): 145-162.

\section{Author biographies}

Tiago Santos Pereira (PhD, University of Sussex) is a Research Fellow at the Centre for Social Studies of the University of Coimbra, Portugal. His research is presently focused on the issues of the governance of science and technology such as expertise, policy-making and participation and the construction of sociotechnical imaginaries.

António Carvalho (PhD, University of Exeter) is an Assistant Professor at the University School of Arts of Coimbra and an Associate Researcher at the Centre for Social Studies of the University of Coimbra. He is currently interested in the social and ethical impacts of the Anthropocene and in the emergence of mindfulness research in the West.

Paulo F.C. Fonseca (PhD, University of Coimbra) is a Postdoctoral Researcher at the Federal University of Santa Catarina, Brazil. In 2014-2015, he was a research fellow at the Harvard Science, Technology and Society Program. His current research examines the governance of science and technology in Brazil. 